\title{
Predicting high and low levels of positive mental health among people living alone in the Lapland region of Finland
}

Pia Crista Milana Solin, Jaakko Reinikainen, Tuija Martelin and Nina Tamminen

\author{
Pia Crista Milana Solin is based \\ at Mental Health Unit, National \\ Institute for Health and Welfare, \\ Helsinki, Finland. \\ Jaakko Reinikainen is based at \\ Public Health Evaluation and \\ Projection Unit, National \\ Institute for Health and Welfare, \\ Helsinki, Finland. \\ Tuija Martelin is based at \\ Equality and Inclusion Unit, \\ National Institute for Health and \\ Welfare, Helsinki, Finland. \\ Nina Tamminen is based at \\ Mental Health Unit, National \\ Institute for Health and Welfare, \\ Helsinki, Finland.
}

\begin{abstract}
Purpose - The purpose of this paper is to investigate positive mental health (PMH) and factors related to it among those living alone in the sparsely populated area of the Lapland region.

Design/methodology/approach - The study utilises data from the Mental Health Survey of the Lapland region in Finland, covering 12 municipalities. The scores of short Warwick-Edinburgh Mental Well-Being Scale (sWEMWBS) were categorised into three levels of PMH. Logistic regression models were used to separately estimate the odds ratios for the high level of PMH compared with the moderate level of PMH and the low level of PMH compared with the moderate level.

Findings - Social support seemed to be very strongly associated with both low and high levels of PMH among people living alone. Participating in activities provided by organisations or societies decreased the odds of having low PMH. Among men, young age predicted low PMH.

Originality/value - The number of people living alone in Finland and other parts of Europe is increasing, yet there are few studies focusing on their positive mental health (PMH). Using scales such as sWEMWBS adds to the authors' knowledge about the positive mental well-being of those living alone, especially in rural areas, thus making it possible to utilise mental health promotion interventions effectively and accordingly.
\end{abstract}

Keywords Positive mental health, Rural area, Living alone, Lapland, Mental well-being

Paper type Research paper

\section{Introduction}

In Finland, there were $1.1 \mathrm{~m}$ people living alone in 2016, and this number is increasing (Statistics Finland, 2016). The same trend can be seen in many high-income countries (Eurostat, 2013). Despite this trend, the few existing studies tend to focus on the negative aspects of life, such as poorer mental health (Borg, 2015; Joutsenniemi et al., 2006), increased mortality (Koskinen et al., 2007) or heavy drinking and alcohol dependence (Joutsenniemi et al., 2007). Overall, data on the population's mental health and its determinants are produced mainly from community epidemiological studies of psychiatric morbidity, which rarely include the positive dimensions of mental health and social well-being (Keyes, 2005). The use of the Warwick-Edinburgh Mental Well-Being Scale (WEMWBS), in its positive focus, not only offers insight into future population mental well-being but also evaluates mental health promotion interventions (Parkinson, 2006). It therefore offers valuable information for decision makers, as it is known that positive mental health $(\mathrm{PMH})$ increases productivity and quality of life, thus being a societally as well as economically important factor.

\section{Living alone}

The studies show that, on average, living alone presents several psychological and social challenges, such as poorer physical health, a higher prevalence of psychological problems and loneliness, poorer quality of life and higher unemployment when compared with those living with 
someone else (Joutsenniemi et al., 2006; Pulkki-Råback et al. , 2012). Those living alone seem to experience lower levels of well-being overall (Kauppinen et al., 2014). In addition, those living alone felt the most dissatisfaction with their economic situation and sexual life. On the other hand, the most important things affecting the well-being of this group were close relationships, contact with nature and health. Health was stated as the most important thing, but their health condition was considered to be only average (Borg, 2015).

\section{The region of Lapland}

The region of Lapland is about 100,366 $\mathrm{km}^{2}$ in size. In 2017, it had a population of 179,281 inhabitants, with a density of 1.93 inhabitants per $\mathrm{km}^{2}$ (Statistics Finland, 2017). Lapland differs from other regions of Finland due to its long distances and its climate (Statistics Finland, 2013). Lapland's climate is subarctic, and it differs between areas within the region. During the Summer, the sun does not set below the horizon in most parts of the region. On the other hand, during the Winter, the polar night may last as long as two months (Finnish Meteorological Institute, 2018). In the FinSote National study of health, well-being and service use, severe mental strain based on the Mental Health Inventory (MHI-5) was found to be more common among women living in Lapland than in other Finnish regions, and self-diagnosed depression was slightly more prevalent than the national average. On the other hand, men living in Lapland felt happier on average than men in other Finnish regions, and self-diagnosed depression was clearly less common among them than the national average (Pentala-Nikulainen et al., 2018).

As the well-being of the Finnish population and its determinants vary in different regions, it is important to have regional information on the $\mathrm{PMH}$ of the inhabitants in order to focus more precisely on their mental health promotion needs (Berry, 2008; Helakorpi et al., 2007).

\section{Positive mental health}

$\mathrm{PMH}$, also referred in some cases as mental well-being, has been shown to be associated with mortality, physical health, social functioning, academic achievement, as well as with mental illness and risk of suicide (Keyes, 2005; Keyes and Simoes, 2012; Teismann et al., 2018).

It is important to make a distinction between other concepts in the area of mental health. According to Putz et al. (2012), mental well-being (in other words, $\mathrm{PMH}$ ) and mental health are different things. Mental well-being describes positive states of being, thinking, behaving and feeling, thus being the counterpart of $\mathrm{PMH}$. On the other hand, mental health is a concept that is often used to incorporate a range of states from good mental health to severe mental health problems (Putz et al., 2012). Furthermore, for several researchers, the term PMH is based on the idea that mental health and mental ill-health are situated in two separate continuums. This viewpoint sees mental health being more than an absence of a diagnosed mental health disorder (Provencher and Keyes, 2011; Keyes and Simoes, 2012; Vaillant, 2012). In other words, those with a mental health disorder may also have $\mathrm{PMH}$ and thus cope with their illnesses better (Keyes, 2005; Keyes and Simoes, 2012; Vaillant, 2012). To sum up, in PMH the focus shifts from problems and disorders into mental resources that can be developed and improved (Keyes and Simoes, 2012; Vaillant, 2012). Furthermore, the determinants of PMH are not necessarily the same as the determinants of mental illness (Huppert, 2008), and therefore, staying mentally healthy is more than merely treating or preventing mental illness.

To measure the positive aspects of mental well-being, a validated WEMWBS can be used. There are two versions: a 7 -item scale and a 14-item scale.

Both versions are easy to use, and they have been utilised in national, regional and local studies around Europe. Furthermore, even the longer version is brief enough to be used in populationlevel surveys (Tennant et al., 2007).

This study aims to investigate $\mathrm{PMH}$ and factors related to it among those living alone in comparison to those living with a partner in a sparsely populated area, in this case, Finnish Lapland. Specifically, we explore which factors are associated with high and low levels of $\mathrm{PMH}$. 


\section{Materials and methods \\ Data}

The data were collected from the Mental Health Survey of Lapland region in Finland during 2012. The aim of the survey was to learn about the population's mental health as well as the factors related to it. The survey covered 12 municipalities in Lapland, the northernmost region of Finland (Nordling and Hätönen, 2013). The sample consisted of 8,200 people aged 15-81 and the number of respondents was 2,746 (response rate 33 per cent). Some of the respondents were excluded because they had reported an age or place of residence that did not belong to the target population or they did not report their household size. We also excluded people who were married or in a relationship and reported that they lived alone. Furthermore, we also excluded those who lived part of the time with someone and part of the time alone. This resulted in data on 2,407 people, of whom 503 lived alone.

\section{Methods}

The questionnaire for collecting the data included the short Warwick-Edinburgh Mental WellBeing Scale (sWEMWBS) (Stewart-Brown et al., 2009) and the three-item Oslo Social Support Scale (Meltzer, 2003) among the basic socio-demographic and other scales.

The sWEMWBS measures positive functioning (energy, clear thinking, self-acceptance, personal development, mastery and autonomy), satisfying interpersonal relationships and positive feelings (feelings of optimism, cheerfulness and relaxation) against seven items. These Likert-style scales produce a single score, and the surveys are self-completed (for people aged 13+) and record the individual's statements about their thoughts and feelings over the past two weeks using positively phrased questions. The items are rated "None of the time", "Rarely", "Some of the time", "Often" and "All of the time" (Stewart-Brown et al., 2009).

The three-item Oslo Social Support Scale (Meltzer, 2003) includes questions about the number of close friends, sense of interest from other people and availability of practical help from neighbours. The total score ranged from 3 to 14 .

\section{Statistical methods}

The sWEMWBS scores were categorised into three levels of PMH: high (more than one standard deviation (SD) above the mean), low (less than one SD below the mean) and moderate (the rest). The mean and SD values were calculated from the entire set of respondents, not only those living alone. Logistic regression models were used to separately estimate the odds ratios for the high level of $\mathrm{PMH}$ compared with the moderate level of $\mathrm{PMH}$, and for the low level of PMH compared with the moderate level. The reason for this kind of separate modelling approach was that previous studies have found different predictors for low and high levels of PMH (Stranges et al., 2014; Stewart-Brown et al., 2015). Descriptive analyses of associations between PMH categories and potential explanatory variables were carried out using $\chi^{2}$-tests.

The set of potential explanatory variables included age, sex, educational level, whether a person is working or studying, frequency of going to spend time in nature, cultural activity, use of cultural services, social support, marital status, and participation in activities of organisations or societies. Variables on cultural activity and the use of cultural services were formed by summarising information from the sets of specific questions using principal components (PCs). The PCs of cultural activity were strongly associated with reading, musical hobbies and handicrafts. The PCs of the use of cultural services had the highest correlation with the use of libraries. The PC variables - age and social support - were used as continuous variables and the others as categorical variables in logistic regressions. We aimed to select the best models that included only important predictor variables for the given outcome to avoid overfitting. Final models for those living alone were selected using the Bayesian information criterion (Schwarz, 1978), but age and sex were always included as adjusting variables. Models with the same variables were also fitted for the data of those not living alone in order to compare the results of those living alone with those not living alone. 
Item non-response was handled using multiple imputation with ten imputed data sets. This was carried out using the R MICE package (van Buuren and Groothuis-Oudshoorn, 2011) with random forest as the imputation method. All the analyses were carried out using $\mathrm{R}$ statistical software version 3.4.0 (R Core Team, 2017).

\section{Results}

Distributions of PMH by the potential explanatory variables are described in Table I separately for those living alone and for those not living alone.

Table I Distributions of PMH by the potential explanatory variables for those living alone and not living alone

\begin{tabular}{|c|c|c|c|c|c|c|c|c|}
\hline & \multicolumn{3}{|c|}{$\begin{array}{c}\text { Living alone } \\
\text { Positive mental health, } n \text { (\%) }\end{array}$} & \multicolumn{5}{|c|}{$\begin{array}{c}\text { Not living alone } \\
\text { Positive mental health, } n \text { (\%) }\end{array}$} \\
\hline & Low & Moderate & High & $p$-value ${ }^{a}$ & Low & Moderate & High & $p$-value ${ }^{a}$ \\
\hline Total & $88(18)$ & $363(72)$ & $52(10)$ & & $238(13)$ & $1351(71)$ & $315(17)$ & \\
\hline \multicolumn{9}{|l|}{ Age } \\
\hline $15-34$ & $14(20)$ & $51(73)$ & $5(7)$ & \multirow[t]{3}{*}{0.185} & $47(14)$ & $256(76)$ & $33(10)$ & \multirow[t]{3}{*}{$<0.001$} \\
\hline $35-54$ & $23(21)$ & $82(74)$ & $6(5)$ & & $80(14)$ & $424(73)$ & $81(14)$ & \\
\hline $55-81$ & $52(16)$ & $230(71)$ & $40(13)$ & & $111(11)$ & $671(68)$ & $201(20)$ & \\
\hline \multicolumn{9}{|l|}{ Sex } \\
\hline Men & $49(24)$ & $133(66)$ & 19 (9) & \multirow[t]{2}{*}{0.006} & $109(14)$ & 535 (69) & $135(17)$ & \multirow[t]{2}{*}{0.166} \\
\hline Women & $39(13)$ & $230(76)$ & $33(11)$ & & $129(11)$ & $816(72)$ & $180(16)$ & \\
\hline \multicolumn{9}{|l|}{ Educational level } \\
\hline Low & $34(18)$ & $138(72)$ & $19(10)$ & \multirow[t]{3}{*}{0.690} & 95 (15) & $430(69)$ & $95(15)$ & \multirow[t]{3}{*}{0.199} \\
\hline Moderate & 44 (19) & $160(70)$ & $25(11)$ & & $102(11)$ & $671(72)$ & $162(17)$ & \\
\hline High & $10(12)$ & $65(79)$ & $8(9)$ & & $41(12)$ & $250(72)$ & $58(17)$ & \\
\hline \multicolumn{9}{|c|}{ In working life or studying } \\
\hline No & $55(17)$ & $227(72)$ & $33(10)$ & \multirow[t]{2}{*}{0.986} & $120(14)$ & $589(67)$ & 170 (19) & \multirow[t]{2}{*}{0.003} \\
\hline Yes & 34 (18) & $136(72)$ & $19(10)$ & & $119(12)$ & $762(74)$ & $145(14)$ & \\
\hline \multicolumn{9}{|l|}{ Going to nature } \\
\hline Often & $24(12)$ & $156(75)$ & $28(13)$ & \multirow[t]{3}{*}{0.017} & $73(9)$ & $584(71)$ & $169(20)$ & \multirow[t]{3}{*}{$<0.001$} \\
\hline Occasionally & $51(20)$ & 179 (72) & $20(8)$ & & $146(14)$ & 732 (72) & 138 (14) & \\
\hline Rarely & $13(29)$ & $28(63)$ & $4(8)$ & & $19(30)$ & $36(57)$ & $9(14)$ & \\
\hline \multicolumn{9}{|l|}{ Cultural activity } \\
\hline Low & $48(27)$ & $116(65)$ & $14(8)$ & \multirow[t]{3}{*}{0.001} & $116(18)$ & $446(68)$ & $94(14)$ & \multirow[t]{3}{*}{$<0.001$} \\
\hline Moderate & $20(17)$ & $91(75)$ & $9(8)$ & & $54(11)$ & $364(73)$ & $79(16)$ & \\
\hline High & $20(10)$ & $156(77)$ & $28(14)$ & & $68(9)$ & $541(72)$ & $143(19)$ & \\
\hline \multicolumn{9}{|c|}{ Use of cultural services } \\
\hline Low & $39(21)$ & $130(71)$ & $15(8)$ & \multirow[t]{3}{*}{0.566} & $99(15)$ & $455(69)$ & 104 (16) & \multirow[t]{3}{*}{0.242} \\
\hline Moderate & $23(17)$ & $100(73)$ & $14(10)$ & & $76(11)$ & $479(72)$ & $113(17)$ & \\
\hline High & $27(15)$ & $132(73)$ & $23(13)$ & & $64(11)$ & 418 (72) & $98(17)$ & \\
\hline \multicolumn{9}{|l|}{ Social support } \\
\hline Low (3-9) & $60(34)$ & $112(64)$ & $3(2)$ & $<0.001$ & $173(29)$ & 385 (65) & $35(6)$ & $<0.001$ \\
\hline Moderate (10-11) & 21 (10) & $158(79)$ & $22(11)$ & & $53(7)$ & $626(80)$ & $106(14)$ & \\
\hline High (12-14) & $8(6)$ & $93(73)$ & $26(20)$ & & $12(2)$ & $340(65)$ & $174(33)$ & \\
\hline Marital status & & & & & & & & \\
\hline Married/cohabiting ${ }^{\mathrm{b}}$ & - & - & - & & $187(11)$ & $1176(71)$ & 290 (18) & $<0.001$ \\
\hline Divorced/widowed & $42(15)$ & 209 (73) & $36(13)$ & 0.040 & $13(20)$ & $44(68)$ & $8(12)$ & \\
\hline Unmarried & $46(21)$ & $154(71)$ & $15(7)$ & & $38(20)$ & $130(70)$ & $18(9)$ & \\
\hline Participation in activ & rovided $b$ & anisations o & ieties dur & e last $12 m$ & & & & \\
\hline No & $64(24)$ & $177(67)$ & $23(9)$ & $<0.001$ & $151(16)$ & $645(70)$ & $127(14)$ & $<0.001$ \\
\hline Yes & $24(10)$ & $186(78)$ & 28 (12) & & $87(9)$ & 706 (72) & 188 (19) & \\
\hline
\end{tabular}

Note: Multiple imputed data are used, so the frequencies are averages across the imputed data sets. ${ }^{a} p$-values from $\chi^{2}$-tests used to determine possible associations between background variables and PMH categories; ${ }^{b}$ those who were married/cohabiting and living alone were removed from the data 
We can see that, overall, low PMH is more common and high PMH less common among people living alone than among those not living alone. The table also shows, for example, that high PMH is most common in the oldest age group among people living with someone; and for those living alone, the proportion of low PMH is larger among men than among women. Spending time in nature, cultural activity, social support and participation in activities provided by organisations or societies seem to be positively related to the level of $\mathrm{PMH}$ in both groups. Divorced/widowed people have higher PMH than those in the unmarried group among those living alone; and married/ cohabiting people have clearly higher levels of $\mathrm{PMH}$ than the other groups among those living with someone else. Being in work life or studying does not seem to be clearly associated with $\mathrm{PMH}$.

The best model (according to the Bayesian information criterion) for low PMH compared with moderate $\mathrm{PMH}$ included age, sex, participation in activities provided by organisations or societies, social support and interaction between age and sex as explanatory variables. The results are presented in Table II and illustrated in Figure 1 to ease interpretation.

Table II Odds ratios (OR), 95\% confidence intervals (CI) and $p$-values for low levels of PMH compared with moderate levels of PMH

\begin{tabular}{|c|c|c|c|c|}
\hline & \multicolumn{2}{|c|}{ Living alone } & \multicolumn{2}{|c|}{ Not living alone } \\
\hline & $\mathrm{OR}(\mathrm{Cl})$ & p-value & OR (Cl) & p-value \\
\hline Age & $0.97(0.95,0.99)$ & 0.013 & $1.01(0.99,1.02)$ & 0.332 \\
\hline \multicolumn{5}{|l|}{ Sex } \\
\hline Men & Ref. & & Ref. & \\
\hline Women & $0.07(0.01,0.49)$ & 0.007 & $2.14(0.79,5.78)$ & 0.134 \\
\hline \multicolumn{5}{|c|}{ Participated in activities provided by organisations or societies during the last 12 months } \\
\hline No & Ref. & & Ref. & \\
\hline Yes & $0.43(0.24,0.75)$ & 0.003 & $0.71(0.52,0.98)$ & 0.037 \\
\hline Social support & $0.68(0.59,0.78)$ & $<0.001$ & $0.57(0.52,0.62)$ & $<0.001$ \\
\hline Age $\times$ Sex (women) & $1.04(1.00,1.07)$ & 0.032 & $0.98(0.96,1.00)$ & 0.020 \\
\hline
\end{tabular}

Figure 1 Predicted probabilities of having low levels of PMH with 95\% point-wise confidence intervals according to age

(a)

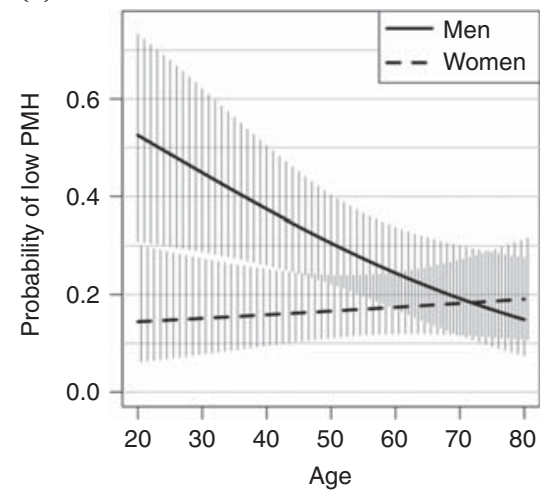

(b)

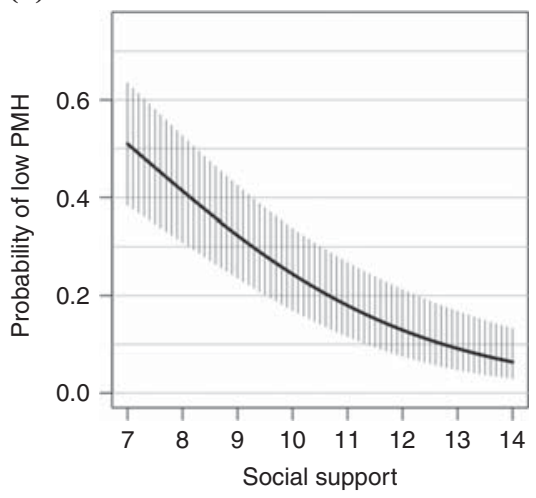

Notes: Predicted probabilities of having low levels of PMH with 95\% point-wise confidence intervals according to age (a) and the level of social support (b), illustrating the results from the logistic regression model for those living alone. Variable values were fixed to: $\operatorname{sex}=$ men, no activity in organisations or societies, social support $=10$ (in (a)) and age $=60($ in $(b))$ 
Among men who live alone, young age predicts low PMH; but for women, age seems to have no effect. Participating in activities provided by organisations or societies decreases the odds of having low PMH. Low social support is clearly related to low PMH. Among those not living alone, results differ a little. Age does not seem to predict $\mathrm{PMH}$ among men; but among women, older age decreases the odds of having low PMH. Activity with organisations or societies decreases the risk of having low $\mathrm{PMH}$, but not so much as among those living alone. Social support is even more strongly negatively associated with low PMH than among people living alone.

The model for high PMH compared with moderate PMH included age, sex and social support as explanatory variables. Table III shows the results and Figure 2 illustrates them.

Old age seems to predict having high levels of PMH in a similar manner to those living alone and for those not living alone. Among people living alone, age does not reach statistical significance, possibly because of the smaller sample size, which also shows up as wider confidence intervals. Social support is a strong predictor of high $\mathrm{PMH}$ and the association is similar among those living alone and not living alone. The data did not give any evidence that sex would be related to having high $\mathrm{PMH}$.

\section{Discussion}

The study scrutinised PMH and factors related to it among those living alone in the sparsely populated area of Lapland and which factors were associated with high and low levels of PMH. Where relevant, some comparison to those not living alone was performed.

Table III Odds ratios (OR), 95\% confidence intervals $(\mathrm{Cl})$ and $p$-values for high levels of
PMH compared with moderate levels of PMH

Figure 2 Predicted probabilities of having a high level of PMH with 95\% point-wise confidence intervals according to age
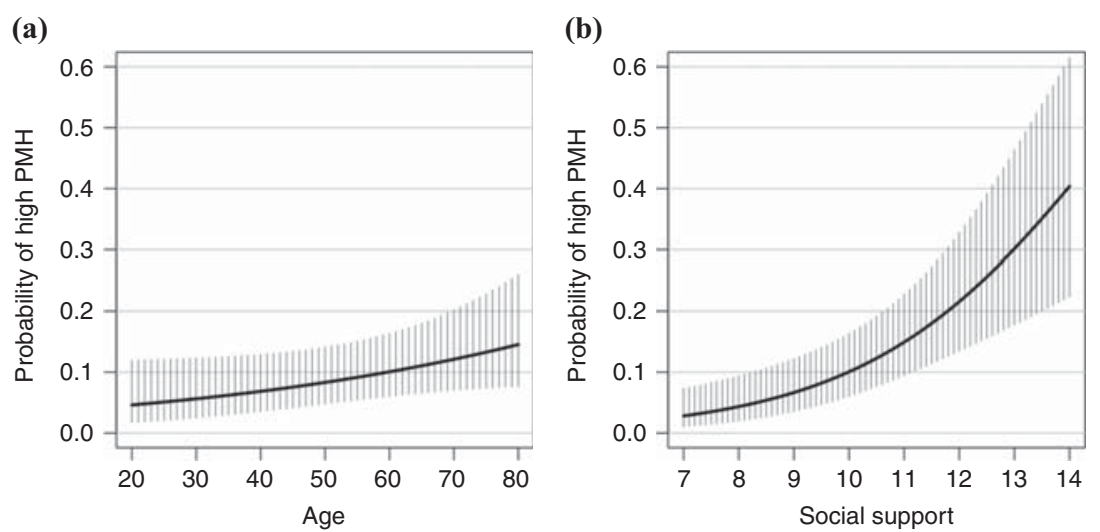

Notes: Predicted probabilities of having a high level of PMH with $95 \%$ point-wise confidence intervals according to age (a) and the level of social support (b), illustrating the results from the logistic regression model for those living alone. Variable values were fixed to: $\operatorname{sex}=$ men, social support $=10$ (in (a)) and age $=60$ (in (b)) 
The region of Lapland offers several divergent factors that may have a negative effect, including long distances and thus fewer social contacts. Equally, this geographical fact could have produced replacing factors which would promote PMH instead of decreasing it, such as enjoying unspoilt nature.

Furthermore, the long-lasting darkness during the polar night may even trigger depression (Nyström et al., 2006). However, Lapland has positive effects as well, such as its nature and unspoilt scenery. There are contradictory studies regarding the living environment. Dreger et al. (2014) did not find a relationship between mental well-being and living in a rural area or in a large city. However, their study did not separate those living alone from those living with someone. On the other hand, Van Lente et al. (2012) found that those living in city areas are not likely to report energy and vitality, which are important components of high PMH. Also Lehtinen et al. (2005) found that living in large cities was associated with poor mental health. The systematic review of Clark et al. (2007) gives cautious suggestion that green and open spaces are linked to better mental health.

According to our study, it seems that social support is clearly related to both low and high PMH. Not participating in activities provided by societies or organisations was strongly associated only with low PMH among those living alone. The relationship was observed to be weaker among those living with someone else, implying that participating in activities would benefit the $\mathrm{PMH}$ of those living alone the most. A tentative suggestion could be that those living alone, especially in rural areas, are more reluctant to attend activities by themselves, while those living with someone else may feel that it is easier to participate with their partner. Furthermore, perhaps living with a partner produces sufficient PMH effects, thus diminishing the need to seek such activities.

As Lapland is sparsely populated area in Finland and thus face-to-face contacts are more scattered than in cities, social support might not have necessarily played such important role among those living alone in Lapland area. Instead it could be possible that other kinds of factors had taken a stronger role in $\mathrm{PMH}$.

According to Chanfreau et al. (2013), living alone was associated with relatively low subjective wellbeing for men, but not for women. It was also found in our study that men living alone experienced low PMH more often than men living with a partner. The trend among women in both groups was similar to men who lived alone, but the difference in low PMH between the two groups of women was much smaller. The study by Dreger et al. (2014) found that living alone is associated with low $\mathrm{PMH}$ among both genders. Furthermore, our study showed that old age seems to predict high levels of PMH for both those who live alone and those not living alone. However, Lukaschek et al. (2017) studied older men and women aged 65-90 years and living alone. They reported that the impact of living alone on low subjective well-being was significant only in women.

According to Borg (2015), mental well-being is formed from the same determinants regardless of whether a person is living alone or with someone else in the same household. Determinants such as social relationships, health, environment and access to nature are essential to both groups. Also, our study showed that the experience of high social support is connected to high PMH in both groups.

\section{Limitations}

When scrutinising this study, selection bias must be taken into account. Those living alone with the best situation in life may have been more disposed to answering the survey, thus leaving us without data from the most excluded group of those living alone (Collier, 1995). Also, information bias may have altered the results. Misinterpretations, memory lapses or modifications to the answers have to be considered (Fadnes et al., 2009).

The response rate was only 33 per cent, which led to the relatively small sample size, and thus it may not have been possible to find all the determinants of high and low PMH. However, even though the sample of those living alone may have been relatively small. As a regional sample of a sparsely populated area, it was quite large.

Cultural variation also has to be taken into consideration, as it seems that experiencing and expressing inner feelings and emotions vary culturally and over time. 


\section{Conclusions}

The study showed that, overall, those living alone in the Lapland region experienced less high PMH and more low PMH than those living with someone. Earlier studies have suggested that there may be variety of determinants affecting PMH of those living alone (Bull and Mittelmark, 2009; Oates et al., 2016). Yet, there are only a few studies focusing on this area (Tamminen et al., 2019), and these seem to present somewhat contradictory results with each other and the study at hand. However, there are several reasons for further studies concerning the PMH of those living alone. First, studies of those living alone as a major population group are scarce, and these have focused only on certain minority groups (such as older people living alone), or those living alone have been studied from a familyoriented perspective. Second, the determinants of $\mathrm{PMH}$ may vary between those living alone and those living with someone else in the same household. What these determinants are and how they affect PMH are not yet clear, thus leaving the needs of a large part of the population unmet. Third, research on interventions focused on those living alone and factors that promote PMH (such as enhancing social support) are limited. Fourth, using sWEMWBS or WEMWBS as a measure of PMH has been unexploited until recently, even though societies should be taking important steps forward in measuring mental healthiness instead of mental illness. Especially mental health policy decision making needs vigorous research data to build efficient objectives for promoting mental well-being of the constantly growing population group of those living alone. Measures focusing entirely on the positive aspects of mental health will also give a novel perspective on well-being. Armed with more knowledge about the $\mathrm{PMH}$ of those living alone, especially in rural areas, would make it possible to use mental health promotion interventions effectively and appropriately.

\section{References}

Berry, H.L. (2008), "Social capital elite, excluded participators, busy working parents and aging, participating less: types of community participators and their mental health", Social Psychiatry and Psychiatric Epidemiology, Vol. 43 No. 7, pp. 527-37.

Borg, P. (2015), "Yksinasuvien Helsinkiläisten kokema hyvinvointi”, Tutkimuksia 2015:3, Helsingin kaupungin tietokeskus, Helsinki.

Bull, T. and Mittelmark, M. (2009), "Work life and mental wellbeing of single and non-single working mothers in Scandinavia", Scandinavian Journal of Public Health, Vol. 37 No. 1, pp. 562-8.

Chanfreau, J., Lloyd, C., Byron, C., Roberts, C., Craig, R., De Feo, D. and McManus, S. (2013), Predicting Wellbeing, Department of Health, London, available at: www.lemosandcrane.co.uk/dev/resources/ predictors-of-wellbeing.pdf (accessed 19 February 2019).

Clark, C., Rowan, M., Stansfield, S.A. and Candy, B. (2007), "A systematic review of the evidence on the effect of the built and physical environment on mental health", Journal of Public Mental Health, Vol. 6 No. 2, pp. 14-27.

Collier, D. (1995), "Translating quantitative methods for qualitative researchers: the case of selection bias", The American Political Science Review, Vol. 89 No. 2, pp. 461-6.

Dreger, S., Buck, C. and Bolte, G. (2014), "Material, psychosocial and sociodemographic determinants are associated with positive mental health in Europe: a cross-sectional study", BMJ Open, Vol. 4, 9pp.

Eurostat (2013), "Distribution of households by household size", available at: http://appsso.eurostat.ec. europa.eu/nui/show.do?dataset=ilc_lvph03\&lang=en (accessed 7 June 2018).

Fadnes, L.T., Taube, A. and Tylleskär, T. (2009), "How to identify information bias due to self-reporting in epidemiological research", The Internet Journal of Epidemiology, Vol. 7, 9pp.

Finnish Meteorological Institute (2018), “Tähtitieteelliset vuodenajat”, available at: http://ilmatieteenlaitos.fi/ tahtitieteelliset-vuodenajat (accessed 28 February 2018).

Helakorpi, S., Laitalainen, E., Absetz, P., Torppa, J., Uutela, A. and Puska, P. (2007), "Aikuisväestön terveyskäyttäytyminen ja terveys maakunnissa 1978-2005”, No. B 15/2007, Kansanterveyslaitoksen julkaisuja, Helsinki.

Huppert, F. (2008), State of Science Review SRX-2: Psychological Wellbeing: Evidence Regarding Its Causes and Consequences. Office of Science and Innovation: Foresight Mental Capital and Wellbeing Project. Mental Capital and Wellbeing: Making the Most of Ourselves in the 21st Century, Government Office for Science \& University of Cambridge, Cambridge. 
Joutsenniemi, K., Martelin, T., Martikainen, P., Pirkola, S. and Koskinen, S. (2006), "Living arrangements and mental health in Finland”, Journal of Epidemiology \& Community Health, Vol. 60 No. 6, pp. 468-75.

Joutsenniemi, K., Martelin, T., Kestilä, L., Martikainen, P., Pirkola, S. and Koskinen, S. (2007), "Living arrangements, heavy drinking and alcohol dependence”, Alcohol \& Alcoholism, Vol. 42 No. 5, pp. 480-91.

Kauppinen, T.M., Martelin, T., Hannikainen-Ingman, K. and Virtala, E. (2014), "Yksinasuvien hyvinvointi. Mitä tällä hetkellä tiedetään”, Työpaperi No. 27/2014, National Institute for Health and Welfare, Helsinki.

Keyes, C. (2005), "Mental illness and/or mental health? Investigating axioms of the complete state model of health", Journal of Consulting and Clinical Psychology, Vol. 73 No. 3, pp. 539-47.

Keyes, C. and Simoes, E. (2012), "To flourish or not: positive mental health and all-cause mortality", American Journal of Public Health, Vol. 102 No. 11, pp. 2164-72.

Koskinen, S., Joutsenniemi, K., Martelin, T. and Martikainen, P. (2007), "Mortality differences according to living arrangements", International Journal of Epidemiology, Vol. 36 No. 1, pp. 1-10.

Lehtinen, V., Sohlman, B. and Kovess-Masfety, V. (2005), "Level of positive mental health in the European Union: results from the Eurobarometer 2002 survey", Clinical Practice and Epidemiology in Mental Health, Vol. 1, 7pp., doi: 10.1186/1745-0179-1-9.

Lukaschek, K., Vanajan, A., Johar, H., Weiland, N. and Ladwig, K. (2017), “'In the mood for ageing': determinants of subjective well-being in older men and women of the population-based KORA-Age study", BMC Geriatrics, Vol. 17, 9pp.

Meltzer, H. (2003), "Development of a common instrument for mental health", in Nosikov, A. and Gudex, C. (Eds), EUROHIS: Developing Common Instruments for Health Surveys, IOS Press, Amsterdam, pp. 35-60, available at: www.euro.who.int/en/publications/abstracts/eurohis-developing-common-instruments-forhealth-surveys (accessed 10 May 2019).

Nordling, E. and Hätönen, H. (2013), "Mielenterveyttä koskeva kyselytutkimus Lapin alueella", unpublished research report, Mielen Tuki project, National Institute for Health and Welfare \& Hospital District of Lapland, Helsinki.

Nyström, M., Saarijärvi, S. and Räihä, H. (2006), "Kaamosmasennus ja kaamosväsymys”, Duodecim, Vol. 122 No. 2, pp. 161-6.

Oates, J., Jones, J. and Drey, N. (2016), "Subjective well-being of mental health nurses in the United Kingdom: results of an online survey", International Journal of Mental Health Nursing, Vol. 26 No. 4, pp. 391-401.

Parkinson, J. (2006), "Measuring positive mental health: developing a new scale", available at: www. healthscotland.scot/media/1718/3047-measuring-mental-well-being-affectometer-2-wemwbs-briefing.pdf (accessed 19 February 2019).

Pentala-Nikulainen, O., Koskela, T., Parikka, S., Kilpeläinen, H., Koskenniemi, T., Aalto, A.-M., Muuri, A., Koskinen, S. and Lounamaa, A. (2018), "Kansallisen terveys-, hyvinvointi ja palvelututkimus FinSoten perustulokset 2017-2018", available at: thl.fi/finsote (accessed 19 February 2019).

Provencher, H.L. and Keyes, C.L.M. (2011), "Complete mental health recovery: bridging mental illness with positive mental health", Journal of Public Mental Health, Vol. 10 No. 1, pp. 57-69.

Pulkki-Råback, L., Kivimäki, M., Ahola, K., Joutsenniemi, K., Elovainio, M., Rossi, H., Puttonen, S., Koskinen, S., Isometsä, E., Lönnqvist, J. and Virtanen, M. (2012), "Living alone and antidepressant medication use: a prospective study in a working-age population", BMC Public Health, Vol. 12 No. 236, 8pp.

Putz, R., O'Hara, K., Taggart, F. and Stewart-Brown, S. (2012), "Using WEMWBS to measure the impact of your work on mental wellbeing: a practice-based user guide", Coventry City Council, Warwick Medical School \& NHS Coventry, available at: www.corc.uk.net/media/1244/wemwbs_practitioneruserguide.pdf (accessed 7 June 2018).

R Core Team (2017), R: A Language and Environment for Statistical Computing, R Foundation for Statistical Computing, Vienna, available at: www.R-project.org/

Schwarz, G. (1978), "Estimating the dimension of a model”, The Annals of Statistics, Vol. 6 No. 2, pp. 461-4.

Statistics Finland (2013), "Maakunnat 2013", available at: www.tilastokeskus.fi/meta/luokitukset/maakunta/ 001-2013/index.html (accessed 7 June 2018).

Statistics Finland (2016), "Suomen virallinen tilasto (SVT): Asunnot ja asuinolot 2016", Tilastokeskus, Helsinki, available at: www.stat.fi/til/asas/index.html (accessed 7 June 2018). 
Statistics Finland (2017), "Suomen virallinen tilasto (SVT): Väestön ennakkotilasto", Tilastokeskus, Helsinki, available at: www.stat.fi/ti/vamuu/index.html (accessed 7 June 2018).

Stewart-Brown, S., Samaraweera, P., Taggart, F., Kandala, N. and Stranges, S. (2015), "Socioeconomic gradients and mental health: implications for public health", British Journal of Psychiatry, Vol. 206 No. 6, pp. 461-5.

Stewart-Brown, S., Tennant, A., Tennant, R., Platt, S., Parkinson, J. and Weich, S. (2009), "Internal construct validity of the Warwick-Edinburgh Mental Well-being Scale (WEMWBS): a Rasch analysis using data from the Scottish Health Education Population Survey", Health and Quality of Life Outcomes, Vol. 19 No. 15, 8pp.

Stranges, S., Samaraweera, P.C., Taggart, F., Kandala, N.B. and Stewart-Brown, S. (2014), "Major healthrelated behaviours and mental well-being in the general population: the health survey for England", BMJ Open, Vol. 4 No. 9.

Tamminen, N., Kettunen, T., Martelin, T., Reinikainen, J. and Solin, P. (2019), "Living alone and positive mental health: a systematic literature review", Systematic Reviews, Vol. 8 No. 134, 8pp.

Teismann, T., Forkmann, T., Brailovskaia, J., Siegmann, P., Glaesmer, H. and Margraf, J. (2018), "Positive mental health moderates the association between depression and suicide ideation: a longitudinal study", International Journal of Clinical and Health Psychology, Vol. 18 No. 1, pp. 1-7.

Tennant, R., Hiller, L., Fishwick, R., Platt, S., Joseph, S., Weich, S., Parkinson, J., Secker, J. and Stewart-Brown, S. (2007), "The Warwick-Edinburgh Mental Wellbeing Scale (WEMWBS): development and UK validation", Health and Quality of Life Outcomes, Vol. 5 No. 63.

Vaillant, G. (2012), "Positive mental health: is there a cross-cultural definition?", World Psychiatry, Vol. 11 No. 2, pp. 93-9.

van Buuren, S. and Groothuis-Oudshoorn, K. (2011), "Mice: multivariate imputation by chained equations in R", Journal of Statistical Software, Vol. 45 No. 3, pp. 1-67.

Van Lente, E., Barry, M.M., Molcho, M., Morgan, K., Watson, D., Harrington, J. and McGee, H. (2012), "Measuring population mental health and social well-being", International Journal of Public Health Research, Vol. 57 No. 2, pp. 421-30.

\section{Corresponding author}

Pia Crista Milana Solin can be contacted at: pia.solin@thl.fi

For instructions on how to order reprints of this article, please visit our website:

www.emeraldgrouppublishing.com/licensing/reprints.htm

Or contact us for further details: permissions@emeraldinsight.com 